\title{
LOCALIZED, DIFFUSE, AND AGGREGATIVE-ADHERING ESCHERICHIA COLI FROM INFANTS WITH ACUTE DIARRHEA AND MATCHED-CONTROLS
}

\author{
MARCELO MAGALHÃES; ROSEMARY J. M. AMORIM; YOSHIFUMI TAKEDA; \\ TEIZO TSUKAMOTO; MARIA G. ANTAS \& SEIKI TATENO
}

\begin{abstract}
Laboratório de Imunopatologia Keizo Asami, Universidade Federal de Pemambuco, Cidade Universitária, \$0670-901 Recife, PE, Brasil
\end{abstract}

Of 126 infants under 2 years, enrolled in a study on the etiology of acute diarrhea in Recife, Brazil, we selected 37 from whom no recognized enteropathogens, except classic enteropathogenic Escherichia coli, were identified. For comparison, we also examined 37 matched-control infants without diarrhea seen at the same hospital setting. This paper had the purpose to determine the prevalence of localized, diffuse, and aggregative-adhering $\mathrm{E}$. coli strains in both groups. Three to five fecal E. coli colonies, of each case and control, were tested individually for adherence to HeLa cells by using the one step 3-h incubation assay. Strains of E. coli showing localized adherence were found significantly more often in patients $(37.8 \%)$ than in controls $(13.5 \%), p$ $<0.02$, and they were practically confined to EPEC serovars 055:H-, 0111:H2, and 119:H6. In contrast, E. coli isolates exhibiting the diffuse or aggregative patterns of adherence were restricted to non-EPEC serogroups and were more frequently encountered among controls.

Key words: adherent Escherichia coli - EPEC - infantile diarrhea

Adhesiveness to epithelial cells is considered as a strong indication of enteropathogenicity for Escherichia coli strains not belonging to invasive or toxigenic groups (Cravioto et al., 1979; Gomes et al., 1989a; Methewson \& Cravioto, 1989). For in vitro adherence assay two cell lines, HEp-2 or HeLa, and two slightly different techniques involving one or two incubations steps are currently in use (Cravioto et al., 1979; Scaletsky et al., 1984).

After being bound to epithelial cells, $E$. coli strains show three distinct morphological patterns of adherence: localized, diffuse, and aggregative (Scaletsky et al., 1984; Nataro et al., 1987). The localized adherence pattern is often exhibited by strains belonging to certain serovars of classic enteropathogenic $E$. coll (EPEC), the most important cause to infantile diarrhea in Brazil (Magalhães et al., 1981; Gomes et al., 1989a; Kitagawa et al., 1989). On the other hand, E. coli strains manifesting diffuse or aggregative patterns of adherence

This work was supported by grants from CNPq (Process $500301 / 88$ ) and Japan International Cooperation Agency.

Received 19 June 1991.

Accepted 5 August 1991. appear not be related to EPEC serovars and their role in diarrheal disease is controversial (Nataro et al., 1987; Levine et al., 1988; Gomes et al., 1989a; Mathewson \& Cravioto, 1989).

In this study we evaluated the potential enteropathogenic role of $E$. coli showing different patterns of adherence to HeLa cells by comparing its prevalence in the stools of infants with diarrhea with that of matched-controls. We also determined which serovars of EPEC are more often associated with localized-adhering strains.

\section{MATERIALS AND METHODS}

Specimens - From February through Junc 1989 , fecal samples were obtained from the first five infants with diarrhea (defined as at least three loose stools in the previous $24 \mathrm{~h}$ ) who visited the outpatient unit or were admitted to Instituto Materno Infantil de Pernambuco, a hospital that assists children from a low socioeconomic background. On the same day or until five days after, a control infant was selected if he did not have a history of diarrhea in the previous seven days. Controls were agematched within 15 days, and also matched concerning the use of antibiotics and previous hospitalization. 
Microbiology - Salmonella, Shigella, Campylobacter, Vibrio, Aeromonas, Plesiomonas, and Yersinia were isolated and classified by standard procedures (Lennette et al., 1985).

Enterohemorrhagic E. coli and EPEC strains were screened by slide agglutination with use of polyvalent and monovalent $\mathrm{OK}$ antisera. Reacting cultures were confirmed by tube agglutination in monovalent $\mathrm{O}$ antisera. All strains belonging to EPEC $O$ serogoups were $\mathrm{H}$ typed, using $\mathrm{Hl}$ to $\mathrm{H} 56$ antisera, by classic methods (Edward \& Ewing, 1962). Specific $\mathrm{O}$ and $\mathrm{H}$ antisera were prepared at the Osaka Prefectural Institute of Public Health, Japan, with reference strains kindly provided by Ida Orskov, Statens Seruminstitut, Copenhagen.

Enterotoxigenic and enteroinvasive $E$. coli strains were identified with DNA specific probes at the Department of Microbiology, Kyoto University, Japan.

Rotavirus and adenovirus particles were visualized under the electron microscope (Barth, 1984).

For detecting Entamoeba histolytica, Giardia lamblia, and Cryptosporidium parvum standard techniques were used (Lennette et al., 1985).

Adherence assay - Three to five $E$. coli colonies, obtained of coprocultures of each case and control, were tested individually for manose-resistant adherence to HeLa cells by the one step 3-h incubation assay, previously described by Cravioto et al. (1979). Briefly, HeLa cells were grown to $50 \%$ confluence on 24 flat bottom well tissue culture plates (Flow Laboratories, Inc., Virginia, USA) in Dulbecco's modified Eagle medium (Gibco Laboratories, Ohio, USA). Monolayers were washed with Hanks balanced salt solution; then fresh medium without antibiotics and containing $1 \%$ D-mannose was added. Bacterial strains were grown overnight in tryptic soy broth, and 20 $\mu l$ of these cultures was added to monolayers. Plates were incubated for $3 \mathrm{~h}$ at $37^{\circ} \mathrm{C}$ in $5 \%$ $\mathrm{CO}_{2}$. Wells were then washed with PBS, fixed with methanol, stained with $10 \%$ Giemsa stain for $30 \mathrm{~min}$, and examined under an inverted microscope. The three previously described patterns of adherence: localized, diffuse, and aggregative were readily discerned (Scaletsky et al., 1984; Nataro et al., 1987).

\section{RESULTS}

During the survey period, 126 fecal samples of infants with diarrhea and 126 of matched controls were studied. As in 89 diarrheal feces, enteropathogens other than EPEC were identified, we restricted our investigation to 37 case-control pairs. This was done because of the difficulty in assessing the potential diarrheagenic role of determined microorganism when it is not detected alone.

Localized adherence was displayed by all 13 EPEC and one non-EPEC strains isolated from patients. Of the five localized-adhering $E$. coli cultures recovered from controls, four belonged to EPEC serovars. Strains exhibiting localized adherence were more often isolated from cases $(37.8 \%)$ than controls $(13.5 \%)$, that is, they were significantly associated with diarrheal disease $(\mathrm{p}<0.02)$. In contrast, $E$. coli strains showing diffuse of aggregative patterns of adherence were more frequently encountered among controls (Table I).

\section{TABLE I}

Adherence to HeLa cells of Escherichia coli isolated from cases without recognized enteric pathogens and from their matched controls

\begin{tabular}{lccc}
$\begin{array}{c}\text { Adherence } \\
\text { pattern }\end{array}$ & $\begin{array}{c}\text { Cases } \\
(\mathrm{n}=37)\end{array}$ & $\begin{array}{c}\text { Controls } \\
(\mathrm{n}=37)\end{array}$ & $P$ value $^{a}$ \\
\hline Localized & $14(37.8)^{b}$ & $5(13.5)$ & $<0.02$ \\
Diffuse & $3(8.1)$ & $6(16.2)$ & $\mathrm{NS}^{c}$ \\
Aggregative & $1(2.7)$ & $2(5.4)$ & $\mathrm{ND}^{d}$ \\
Nonadherent & $19(51.4)$ & $24(64.9)$ & $\mathrm{NS}$ \\
\hline
\end{tabular}

$a$ : determined by $\chi^{2}$ test; $b$ : number (\%) of children whose coprocultures furnished at least one $E$. coli colony showing indicated pattern of adherence; $c$ : not significant; $d$ : not determined.

Of the 17 EPEC strains recovered from cases and controls, $12(70.6 \%)$ were confined to only three serovars: $\mathrm{O} 55: \mathrm{H}-, \mathrm{O} 111: \mathrm{H} 2$, and O119:H6 (Table II). Cultures manifesting diffuse or aggregative adherence patterns belonged to serogroups different from EPEC. 
TABLE II

EPEC serovars showing localized adherence and their distribution among 37 cases and 37 controls in Recife, Brazil

\begin{tabular}{lll}
\hline & \multicolumn{2}{c}{ Adherent strains } \\
\cline { 2 - 3 } EPEC serovars & $\begin{array}{c}\text { Cases } \\
\text { No. }(\%)\end{array}$ & $\begin{array}{l}\text { Controls } \\
\text { No. }(\%)\end{array}$ \\
\hline $044: \mathrm{H}-$ & 0 & $2(100)$ \\
$055: \mathrm{H}-$ & $2(66.7)$ & $1(33.3)$ \\
$086: \mathrm{H} 34$ & $1(100)$ & 0 \\
$0111: \mathrm{H} 2$ & $5(100)$ & 0 \\
$0111: \mathrm{H} 6$ & $1(100)$ & 0 \\
$0111: \mathrm{HNT}$ & $1(100)$ & 0 \\
$0119: \mathrm{H} 6$ & $3(75)$ & $1(25)$ \\
None & $1(50)$ & $1(50)$ \\
\hline
\end{tabular}

\section{DISCUSSION}

Present results are similar to those obtained in other surveys, carried out in South America, showing that localized adherence is a property linked to determined EPEC serovars and that diffuse or aggregative patterns of adherence are distributed almost exclusively among nonEPEC strains (Cravioto et al., 1979; Nataro et al., 1985; Levine et al., 1988; Gomes et al., $1989 \mathrm{~b}$ ). In fact; localized adherence was almost exclusively confined to EPEC strains of the serovars O55:H-, O111:H2, and O119:H6. Thus, also in this aspect, our results are identical to those observed in São Paulo, Peru, and Chile (Nataro et al., 1985; Levine et al., 1988; Gomes et al., 1989b). This serovar occurrence of localized-adhering EPEC, however, may vary geographically. In Thailand, for instance, strains with localized adherence were all restricted to 0119 serogroup (Echeverria et al., 1987).

Whereas these results point out that localized-adhering EPEC strains are associated with infantile diarrhea in Recife, their statistical significance was lower than that observed in São Paulo. In the study carried out by Gomes et al. (1989a), a $P$ value $<0.0001$ was obtained. This higher etiopathogenic performance would be attributable to a more stringent condition required for the choice of controls in that study. We recruited controls among children free of diarrhea for only seven days. Accordingly, it is possible that some of our controls were still shedding EPEC after the clinical cure of a recent diarrheal episode. An alternative expla- nation would be related to regional differences. It is a characteristic of the infantile diarrheal disease in Recife the isolation of multiple enteropathogens from patients and healthy controls. In this series, for instance, among the 126 patients and 126 controls, first selected for the study, mixed infections were respectively detected in 46 and $22.2 \%$. Moreover, many recognized enteropathogens current in other areas, such as Campylobacter, Salmonella, some EPEC serovars, enterotoxigenic $E$. coli, adenovirus, Entamoeba histolytica, and Giardia lamblia were highly prevalent among non-diarrheal infants (Magalhães et al., 1990). Opportunity for spread of enteropathogens in Northeastern, the poorest region of Brazil, is provided by the frequent environmental contamination by fecal organism, as a lack of household sanitary-facilities (Guerrant et al., 1983).

Escherichia coli strains manifesting diffuse adherence were more frequently found among controls. Nowadays, after accurate pattems of adhesiveness have clearly been defined (Nataro et al., 1987; Vial et al., 1990), that observation is a commonplace (Nataro et al., 1987; Levine et al., 1988; Gomes et al., 1989a; Cobeljic et al., 1990). Indeed, epidemiologic evidence does not support the ability of diffuse-adhering strains to cause diarrhea (Mathewson \& Cravioto, 1989). Nevertheless, a recent community-based case control survey, carried out in a Mexican Mayan village, showed that $E$. coli with diffuse adherence was the single infectious agent that could be associated with diarrhea (Girón et al., 1991). Since we have used the same technique to assay adherence as that used in Mexican study, the discrepancy between results might be credited to differences in epidemiologic and microbiologic methodologies. In the investigation of Girón et al. (1991) the age limit was six years and the patients were sought in the community, a conduct that permitted to include mild cases of diarrhea. In fact, when patients are selected at hospitals as were ours, sample is biased because only severe diarrheal cases and patients with possibilities to arrive to hospital enter in the study. On the other hand, in Mexican survey important enteropathogens, such as rotavirus, salmonella, enteroinvasive $E$. coli, EPEC, and protozooa, have not been detected or even searched. In addition, diffuse-adhering $E$. coli cultures diverge from those with localized or aggregative adherence patterns because they are not able to produce experimental diar- 
rhea in human volunteers (Taccket et al., 1990). Such failure in producing experimental disease suggests that diffuse adherence is not a marker of enteropathogenicity of $E$. coli. Thus, new surveys in communities will be needed before we decide whether the capacity in producing diarrhea of diffuse adhering- $E$. coli is confined to unique rural areas.

Previous studies evaluating the role played by aggregative-adhering $E$. coli in the etiology of infantile diarrhea also have yielded discrepant results (Levine et al., 1988; Vial et al., 1988; Gomes et al., 1989a). These conflicting findings have subsequently been assigned to technical differences in the performance of the adherence cell assay (Vial et al., 1990). In fact, as an indication of pathogenic potentiality, enteroaggregative $E$. coli is able to produce characteristics lesions in rabbit and rat ileal loops after challenging (Vial et al., 1988). Nevertheless, it appears that discrepant conclusions on the capacity of aggregative-adhering E. coli to induce diarrhea is not solely assay dependent. In a case control study carried out in Chile by Nataro et al. (1987), the microorganism was significantly associated with infantile diarrhea $(P<0.00001)$. In India, however, though Bhan et al. (1989) found a significative association of enteroaggregative $E$. coli with protracted diarrhea, the organism could not be linked to acute episodes. Present results also did not favor entero-aggregative $E$. coli in causing acute infantile diarrhea in Recife.

\section{ACKNOWLEDGEMENTS}

To Miss Eliete C. da Silva, Marlene Andrade, and Vilma M. Melo for technical assistance in adherence assays.

\section{REFERENCES}

BARTH, O. M., 1984, Estudo sobre a contrastação negativa de suspensões virais. Rev. Bras. Biol., 44: $71-80$.

BHAN, M. K.; RAJ, P.; LEVINE, M. M.; KAPER, J. B.; BHANDARI, N.; SRIVASTAVA, R.; KUMAR, R. \& SAZAWAL, S., 1989. Enteroaggregative Escherichia coli associated with persistent diarrhea in a cohort of rural children in India. J. Infect. Dis., 159: 1061-1064.

COBELJIC, M.; STOJILJKOVIC, I.; LEPSANOVIC, Z. \& LERS, N., 1990. Lack of association of Escherichia coli exhibiting both manose-resistant haemagglutination and diffuse adherence to HEp2 cells with acute diarthoea in children. Epidemiol. infect., 104: 127-133.
CRAVIOTO, A.; GROSS, R. J.; SCOTLAND, S. M. \& ROWE, B., 1979. An adhesive factor found in strains of Escherichia coli belonging to the traditional infantile enteropathogenic serotypes. Current Microbiol., 3: 95-99.

ECHEVERRIA, P.; TAYLOR, D. N.; ROLFE, A. D.; SUPAWAT, K.; RATCHTRACHENCHAI, O.; KAPER, J. \& KEUSCH, G. T., 1987. HeLa cell adherence and cytotoxin production by enterotoxigenic Escherichia coli isolated from infants with diarrhea in Thailand. J. Clin. Microbiol, 25: 1519 1523.

EDWARDS, P. R. \& EWING, W. H., 1962. Identification of Enterobacteriaceae. 2nd ed. Burgess Publishing Company, Minneapolis, xviii +362 .

GIRÓN, J. A.; JONES, T.; MILLAN-VELASCO, F.; CASTRO-MUNHOZ, E.; ZARATE, L.; FRY, J.; FRANKEL, G.; MOSELEY, S. L.; BAUDRY, B.; KAPER, J. B.; SCHOLNIK, G. K. \& RILEY, L. W., 1991. Diffuse-adhering Escherichia coli (DAEC) as a putative cause of diarrhea in Mayan children in Mexico. J. Infect. Dis., 163: 507-513.

GOMES, T. A. T.; BLAKE, P. A. \& TRABULSI, L. R., 1989a. Prevalence of Escherichia coli strains with localized, diffuse, and aggregative adherence to HeLa cells in infants with diarrhea and matched controls. J. Clin. Microbiol., 27: 266-269.

GOMES, T. A. T.; VIEIRA, M. A. M.; WACHSMUTH, I. K.; BLAKE, P. A. \& TRABULSI, L. R., 1989b. Serotype specific prevalence of Escherichia coli strains with EPEC adherence factor genes in infants with and without dianhea in Sao Paulo, Brasil. J. Infect. Dis., 160: 131-135.

GUERRANT, R. L.; KIRCHOFF, L. V.; SHILDS, D. S.; NATIONS, M. K.; LESLIE, J.; deSOUZA, $M$. A.; ARAUJO, J. G.; CORREIA, L. L.; SAUER, K. T.; McCLELLAND, K. E.; TROWBRIDGE, F. L. \& HUGHES, J. M., 1983. Prospective study of diarrheal illnesses in Northeastern Brazil: patterns of disease, nutritional impact, etiologies and risk factors. $J$. Infect. Dis., 148: 986-997.

KITAGAWA, S. M. S.; TOLEDO, M.R. F.; TRABULSI, L. R.; RAMOS, S. R. T. S.; MURAHOVSCHI, J.; FAGUNDES NETO, U. \& CANDEIAS, J. A. N., 1989. Etiologia da diarréia infecciosa endêmica da criança de baixo nivel sócio-econômico em São Paulo. Rev. Paul. Pediatr., 7: 16-25.

LENNETTE, E. H.; BALOWS, A.; HAUSLER JR, W. J. \& SHADOMY, H. J., I985. Manual of clinical microbiology. 4th ed. American Society for Microbiology, Washington, D. C., $\mathrm{xx}+1149$ p.

LEVINE, M. M.; PRADO, V.; ROBINS-BROWNE, R.; LIOR, H.; KAPER, J. B.; MOSELEY, S. L.; GICQUELAIS, K.; NATARO, J. P.; VIAL, P. \& TALL, B., 1988. Use of DNA probes and HEp-2 cell adherence assay to detect diarrheagenic Escherichia coli. J. Infect. Dis., 158: 224-228.

MAGALHĀES, M.; ANDRADE, M. \& CARVALHO, A. E., 1981. Pathogenic Escherichia coli associated with infantile diarrhea. Rev. Microbiol. (S. Paulo), 12: 38-41.

MAGALHÃES, M.; LINHARES, M. I.; ANDRADE, G. P.; ACA, 1.; TAKEDA, Y; OKUZAWA, E. \& TATENO, S., 1990. Microbiologia da diarréia aguda endêmica em crianças do Recife. Rev. IMIP, 4: 2328. 
MATHEWSON, J. J. \& CRAVIOTO, A., 1989. HEp-2 cell adherence as an assay for virulence among diarrheagenic Escherichia coli. J. Infect. Dis., 159: $1057 \cdot 1060$.

NATARO, j. p; KAPER, J. B.; ROBINS-BROWNE, R.; PRADO, V.; VIAL, P. \& LEVINE, M. M., 1987. Patterns of adherence of diarrheagenic Escherichia coli to Hep-2 cells. Pediatr. infect. dis., 6: 829831 .

SCALETSKY, I. C. A.; SILVA, M. L. M. \& TRABULSI, L. R., 1984. Distinctive patterns of adherence of enteropathogenic Escherichia coli to HeLa cells. Infect. Immun., 41: 1340-1351.

TACKET, C. O.; MOSELEY, S. L.; KAY, B.; LOSONSKY, G. \& LEVINE, M. M., 1990. Chal- lenge studies in volunteers using Escherichia coli strains with diffuse adherence to HEp-2 cells. J. Infect. Dis., 162: 550-552.

VIAL, P. A.; ROBINS-BROWNE, R. M.; LIOR, H.; PRADO, V.; KAPER, J. B.; ELSAYED, A. \& LEVINE, M. M., 1988. Characterization of enteroadherent-aggregative Escherichia coli, a putative agent of diarrheal disease. J. Infect. Dis., 158: 70-79.

VIAL, P. A.; MATEWSON, J. J.; DuPONT, H. L.; GUERS, L. \& LEVINE, M. M., 1990. Comparison of two assay methods for patterns of adherence to HEp-2 cells of Escherichia coli from patients with diarrhea. J. Clin. Microbiol., 28: $882-885$. 